medRxiv preprint doi: https://doi.org/10.1101/2020.06.19.20135897; this version posted June 20, 2020. The copyright holder for this preprint (which was not certified by peer review) is the author/funder, who has granted medRxiv a license to display the preprint in perpetuity.

All rights reserved. No reuse allowed without permission.

Bennett-Sex Differences in Fighters

\title{
Sex Moderates the Relationship that Number of Professional Fights has with Cognition and Brain Volumes
}

Lauren L. Bennett, ${ }^{1}$ Steve Stephen, ${ }^{2}$ Charles Bernick, ${ }^{3}$ Guogen Shan, ${ }^{4}$ and Sarah J. Banks ${ }^{5}$

${ }^{1}$ Neuropsychologist, Pickup Family Neurosciences Institute, Hoag Memorial Hospital

Presbyterian, 1 Hoag Dr., Newport Beach, 92663 Email: Lauren.Bennett@Hoag.org Phone

Number: 949-764-6822 Fax Number: 949-764-8540

${ }^{2}$ Visiting Researcher, Cleveland Clinic Lou Ruvo Center for Brain Health 888 W. Bonneville

Ave., Las Vegas, NV 89106 Email: Stephes5@ccf.org Fax Number: 702-701-7954.

${ }^{3}$ Assistant Medical Director, Cleveland Clinic Lou Ruvo Center for Brain Health 888 W.

Bonneville Ave., Las Vegas, NV 89106. Email: BernicC@ccf.org Phone Number: 702-483-6030

Fax Number: 702-701-7954

${ }^{4}$ Associate Professor of Biostatistics, Department of Environmental and Occupational Health, School of Community Health Sciences, University of Nevada Las Vegas, Las Vegas, Nevada, 89154 Email: guogen.shan@unlv.edu Phone number: 702-895-4413

${ }^{5}$ Director of Neuropsychology, Multidisciplinary Memory Clinic, University of California, San Diego, 9444 Medical Center Drive \#1-100, La Jolla, CA 92037 Email: sbanks@ucsd.edu Phone number: 858-246-1264 Fax: 858-246-1287

Word Count: 3,315 
medRxiv preprint doi: https://doi.org/10.1101/2020.06.19.20135897; this version posted June 20, 2020. The copyright holder for this preprint (which was not certified by peer review) is the author/funder, who has granted medRxiv a license to display the preprint in perpetuity.

All rights reserved. No reuse allowed without permission.

Bennett-Sex Differences in Fighters

\begin{abstract}
Objective: Incidence of concussions and report of symptoms are greater amongst women across sports. While structural brain changes and cognitive declines are associated with repetitive head impact (RHI), the role of sex is not well understood. This study aimed to determine if there is a moderating effect of sex on the relationship number of professional fights has with cognitive functioning and regional brain volumes in a cohort of boxers, mixed martial artists, and martial artists.
\end{abstract}

Methods: 55 women were matched with 55 men based on age, years of education, ethnicity, and fighting style. Cognition was assessed via CNS Vital Signs computerized cognitive battery and supplemental measures. Structural brain scans, demographic data, and number of professional fights (NoPF) were also considered. Matched pairs were compared via analysis of covariance, accounting for total brain volume. Within-subject moderation models were utilized to assess the moderating effect of sex on the relationship between NoPF and brain volumes and cognitive performance.

Results: Men were observed to have poorer performance on measures of psychomotor speed when compared to women. On a series of analyses assessing the role of sex as a moderator of the relationship between NoPF and regional brain volumes/cognitive performance, a significant moderation effect was observed across multiple measures of cognitive functioning, such that men had poorer performance. Differences in numerous regional brain volumes were also observed, such that the relationship between NoPF and brain volumes was steeper amongst men. Conclusion: Sex was observed to be an important moderator in the relationship between NoPF, aspects of cognitive functioning, and volumes of numerous brain regions, suggesting that sex differences in neuroanatomic and cognitive response to RHI deserve further attention. 
medRxiv preprint doi: https://doi.org/10.1101/2020.06.19.20135897; this version posted June 20, 2020. The copyright holder for this preprint (which was not certified by peer review) is the author/funder, who has granted medRxiv a license to display the preprint in perpetuity.

All rights reserved. No reuse allowed without permission.

\section{Bennett-Sex Differences in Fighters}

Key Terms: sex differences, sports-related concussion, repetitive head impacts, boxing, martial arts, mixed martial arts 
medRxiv preprint doi: https://doi.org/10.1101/2020.06.19.20135897; this version posted June 20, 2020. The copyright holder for this preprint (which was not certified by peer review) is the author/funder, who has granted medRxiv a license to display the preprint in perpetuity.

All rights reserved. No reuse allowed without permission.

Bennett-Sex Differences in Fighters

\section{INTRODUCTION}

Multiple epidemiological studies have demonstrated that male athletes have been shown to be at lower risk for sports-related concussion than female athletes within both practice and competition across numerous sports (Merritt, Padgett, \& Jak, 2019). Specifically, women participating in basketball, soccer, lacrosse, softball/baseball, tennis, outdoor track, and crosscountry are at increased risk for sustaining a concussion than men (Lincoln et al., 2011; Marar, McIlvain, Fields, \& Comstock, 2012; Zuckerman et al., 2015). Moreover, following head injury, female athletes have been found to endorse greater severity of concussion-related symptoms, demonstrate greater declines in cognitive functioning, and slower physiological recovery postinjury. Prior research suggests there are sex differences in the changes to both structural and metabolic brain functioning following concussions for athletes participating in other sports (i.e., ice hockey, soccer, water polo; Chamard, Lefebvre, Lassonde, \& Theoret, 2016; Covassin, Elbin, Bleecker, Lipchik, \& Kontos, 2013; Covassin, Moran, \& Elbin, 2016; Fakhran, Yaeger, Collins, \& Alhilali, 2014; Frommer et al., 2011; Sollmann et al., 2018). Very little research has been completed in sex differences in male and female professional fighters (Merritt et al., 2019)

In addition, recent professional fight records comparing fight outcomes across men and women may be an indication of different rates of repetitive head impact exposure, suggesting need for further exploration of sex differences. When examining Nevada state fight records from 2015 through 2017, it appears women are less likely to be knocked out (KO) or sustain a technical knockout (TKO) than male fighters, overall (please see Table 1; Nevada State Athletic Commission, n.d.). This data is in contrast to the higher rate of concussions observed amongst female athletes who participate in most other sports. Notably, as fewer women compete in combat sports, it is difficult to determine if the same trend would exist if the samples were to be 
medRxiv preprint doi: https://doi.org/10.1101/2020.06.19.20135897; this version posted June 20, 2020. The copyright holder for this preprint (which was not certified by peer review) is the author/funder, who has granted medRxiv a license to display the preprint in perpetuity.

All rights reserved. No reuse allowed without permission.

Bennett-Sex Differences in Fighters

equal sized. To date, the relationship between sex, regional brain volumes, and cognitive performance amongst male and female professional fighters has not been examined. This study aimed to investigate if there is a differential effect of sex on the relationship that number of professional fights (NoPF) has with cognitive functioning and brain region volumes in professional fighters.

\section{[PLEASE INSERT TABLE 1 HERE]}

\section{METHODS}

\section{Study design}

Participants were drawn from an ongoing longitudinal observational study of professional combat sport athletes, the Professional Fighters Brain Health Study (PFBHS; Bernick et al., 2013). As part of the PFBHS, participants are assessed at baseline and at subsequent one-year intervals. For the purposes of this study, baseline imaging, demographic, number of professional fights, and cognitive functioning data were considered. Given the small number of women with longitudinal data, we restricted the current analysis to the baseline data, thus we report crosssectional analyses here. While collected, self-report of number of amateur fights and concussions were excluded from analyses as these data reflect high levels of variability and are uncorroborated. Since the number of professional fights (NoPF) could be validated, it was used as a proxy for repetitive head impact exposure with consideration of training exposure, in addition to exposure during the actual match.

The study was approved by the local institutional review board (\#10-944) and written informed consent was obtained from all study participants. Study visits for all participants included in these analyses were performed at the Cleveland Clinic Lou Ruvo Center for Brain 
medRxiv preprint doi: https://doi.org/10.1101/2020.06.19.20135897; this version posted June 20, 2020. The copyright holder for this preprint (which was not certified by peer review) is the author/funder, who has granted medRxiv a license to display the preprint in perpetuity.

All rights reserved. No reuse allowed without permission.

Bennett-Sex Differences in Fighters

Health in Las Vegas, Nevada between 03/30/2011 and 10/18/2017. For a detailed explanation of study methods see Bernick et al (2013).

\section{Participants}

The study cohort consisted of all 55 women fighters enrolled in the PFBHS to date and 55 male fighters who were matched with the female fighters on the following variables: age, years of education, ethnicity, and type of competitive fighting, including boxing, mixed martial arts, and martial arts (e.g. kickboxing, Muay Thai, judo). Both retired and active professional fighters were included in the analyses for this study. Participants were not seen for their baseline or follow up visits for at least 45 days following their most recent fight.

\section{Cognitive and psychological assessment}

Participants completed a short battery of computerized cognitive and motor tests including symbol digit coding, finger-tapping, and Stroop-like tasks from the CNS Vital Signs program (Gualtieri \& Johnson, 2006). Performance across CNS Vital Sign subtests produced composite score of the following domains: Verbal Memory (word list recognition), Processing Speed (the number of correctly completed items on symbol digit coding, while accounting for incorrect responses), Psychomotor Speed (bilateral finger-tapping speed and number correct on a digit symbol digit coding task), and Reaction Time (response time on Stroop-like tasks). Prior research has found that men perform significantly better on right-sided finger-tapping, but no other significant sex-based performance differences were observed (Iverson, Brooks, \& Ashton Rennison, 2014).

Beyond the CNS Vital Signs battery, fighters completed six additional measures of cognitive functioning during assessment, including supplemental measures of processing speed (a timed reading passage and a computerized version of Trails A via the iCOMET battery 
medRxiv preprint doi: https://doi.org/10.1101/2020.06.19.20135897; this version posted June 20, 2020. The copyright holder for this preprint (which was not certified by peer review) is the author/funder, who has granted medRxiv a license to display the preprint in perpetuity.

All rights reserved. No reuse allowed without permission.

Bennett-Sex Differences in Fighters

[speeded connection of numeric dots]), language (semantic fluency [ability to name items belonging to given a semantic category], a word task [ability to pronounce words with irregular, non-phonetic spellings]), executive functioning (letter fluency [ability to generate words beginning with given letter], and a computerized version of Trails B via the iCOMET battery [speeded, alternating connection of numeric and alphabetic dots]).

\section{Imaging}

Brain MRI scans were conducted on a MAGNETOM Verio 3-tesla scanner (Siemens Medical Systems, AG, Erlangen, Germany) with volumetric values derived from T1-weighted images via FreeSurfer, version 6 (Fischl, 2012).

Volumetric segmentation was completed on the MPRAGE sequence using the Freesurfer Version 6.0 image analysis suite. Conventional sagittal 3D magnetization-prepared rapid acquisition with gradient echo (MPRAGE) T1 (voxel size $=1 \times 1 \times 1.2 \mathrm{~mm}$; flip angle/repetition time $[\mathrm{TR}] /$ echo time $[\mathrm{TE}] /$ inversion time $[\mathrm{TI}]=9 / 2300 / 2.98 / 900 \mathrm{~ms}$; scan time $=9: 14)$, axial turbo spin-echo $(\mathrm{TSE}) \mathrm{T} 2($ voxel size $=0.8 \times 0.8 \times 4 \mathrm{~mm}$; TR/TE $=5000 / 84 \mathrm{~ms} ; 38$ slices; scan time $=0: 57)$, axial TSE fluid-attenuated inversion recovery $($ voxel size $=0.8 \times 0.8 \times 4 \mathrm{~mm}$; $\mathrm{TR} / \mathrm{TE} / \mathrm{TI}=7000 / 81 / 2220 \mathrm{~ms} ; 38$ slices; scan time $=2: 36)$, and axial susceptibility weighted imaging $(\mathrm{SWI})($ voxel size $=0.9 \times 0.9 \times 0.9 \mathrm{~mm} ; \mathrm{TR} / \mathrm{TE}=20 / 27 \mathrm{~ms} ; 36$ slices; scan time $=1: 17)$ sequences were used for this study.

Volumetric segmentation was performed on the MPRAGE sequence using the Freesurfer Version 6.0 image analysis suite (http://surfer.nmr.mgh.harvard.edu/). Procedures for measuring cortical thickness have been validated against histological analysis and manual measurements. Freesurfer morphometric procedures have demonstrated good test-retest reliability across scanner manufacturers and across field strengths. 
medRxiv preprint doi: https://doi.org/10.1101/2020.06.19.20135897; this version posted June 20, 2020. The copyright holder for this preprint (which was not certified by peer review) is the author/funder, who has granted medRxiv a license to display the preprint in perpetuity.

All rights reserved. No reuse allowed without permission.

Bennett-Sex Differences in Fighters

\section{Analyses}

Guided by prior findings from the PFBHS, as well as other studies highlighting structural and metabolic changes following repetitive head impact, the following brain regions were chosen a priori for examination: the putamina, hippocampi, amygdalae, caudates, and thalami (Bernick \& Banks, 2013; Bernick et al., 2015; Chamard et al., 2016; Lee, Bennett, Bernick, Shan \& Banks, 2019; Schultz et al., 2018). When applicable, both left and right sides of brain regions were evaluated. Additionally, total brain volume was controlled for in all imaging analyses. Moderation analyses were conducted in SAS, version 9. All other analyses were conducted in SPSS version 23.

Analysis of variance tests were run to examine group differences between female and male fighters on the four CNS Vital Signs composite scores (Verbal Memory, Processing Speed, Psychomotor Speed, Reaction Time), as well as supplemental measures of processing speed (timed reading task, computerized version of Trails A), language (semantic fluency), and executive functioning (letter fluency, computerized version of Trails). Analysis of covariance tests were run to examine group differences across regional brain volumes between male and female fighters, while accounting for total brain volume. To assess the moderating role of sex in the relationship between fight exposure and regional brain volumes and cognitive performance, a series of within-subject moderation models were computed.

Twenty models were computed, one for each of the five brain regions identified a priori and each of the 10 cognitive outcome measures. Sex as a moderator within models was considered at $p<.05$. Exploratory analyses to characterize models were considered at $p<.05$.

\section{RESULTS}

\section{Demographic data}


medRxiv preprint doi: https://doi.org/10.1101/2020.06.19.20135897; this version posted June 20, 2020. The copyright holder for this preprint (which was not certified by peer review) is the author/funder, who has granted medRxiv a license to display the preprint in perpetuity.

All rights reserved. No reuse allowed without permission.

Bennett-Sex Differences in Fighters

Fighters ranged in age from 19 to 55 years, with a mean age of $30.70(\mathrm{SD}=6.7)$. Of the 110 fighters, 101 were active fighters consisting of 52 men and 49 women. Of the 9 retired fighters, 3 were men and 6 were women. Participants were encouraged to select all race categories that applied to them. Self-defined race was $69 \%(n=76)$ white; $13 \%(n=14)$ black; $8 \%(n=9)$ other; $6 \%(n=6)$ Pacific Islander; 3\% $(n=3)$ Asian. Four participants $(n=4)$ did not provide their race. The majority of fighters identified as mixed martial artists (MMAs; $n=64$ ). The mean number of years of education completed was $14.46(\mathrm{SD}=2.0)$. As participants were matched, there were no significant differences between male and female fighters with regard to age, years of education, ethnicity, and type of fighting (e.g., boxer, MMA, MAs; all p's > .2). Fighters had a mean of 12.8 professional fights $(\mathrm{SD}=15.8)$. Female and male fighters did not significantly differ in the number of professional fights fought $(p=.764)$. Additional demographic data are presented in Table 2.

\section{[PLEASE INSERT TABLE 2 HERE]}

\section{Sex differences in regional brain volumes}

ANCOVAs were conducted to assess differences in regional brain volumes while controlling for total brain volume. Female fighters $($ mean $=1624.18)$ differed significantly from male fighters $($ mean $=1669.05)$ in left amygdala $(F(1,106)=8.417 ; p=.005)$, when accounting for total brain volume. In contrast, the right amygdala, bilateral hippocampi, thalamus, and caudate volumes were not significantly different as a function of sex (all $p$ 's $>.05$ ). These results suggest that female fighters have larger left amygdala than their male fighter counterparts.

\section{Sex differences in cognitive performance}

Male fighters had poorer performance on CNS Vital Signs Psychomotor Speed measures $(F(1,106)=8.32 ; p=.005)$. There were no significant differences on CNS Vital Signs 
medRxiv preprint doi: https://doi.org/10.1101/2020.06.19.20135897; this version posted June 20, 2020. The copyright holder for this preprint (which was not certified by peer review) is the author/funder, who has granted medRxiv a license to display the preprint in perpetuity. All rights reserved. No reuse allowed without permission.

Bennett-Sex Differences in Fighters

composite scores of Verbal Memory, Processing Speed, and Reaction Time (all $p$ ’s $>.05$ ).

Similarly, there were no significant difference on supplement cognitive functioning measures of processing speed (Trails A and passage reading time), language (semantic fluency and word reading), and executive functioning (Trails B and letter fluency) performance as a function of sex (all $p$ 's $>.05)$. All analyses accounted for education.

\section{Sex as a moderator of the relationship between fight exposure and regional brain volumes}

In order to explore the role of sex as a moderator of the relationship between fight exposure and regional brain volumes, a series of within-subject moderation analyses were computed according to the above-stated parameters. A significant moderation effect of sex was observed on right hippocampus, right thalamus, left putamen, left amygdala, and right amygdala (please see Figure 1A-E and Table 3). While smaller right hippocampus, right thalamus, left putamen, and bilateral amygdala was associated with greater fight exposure in both men and women, the relationship between number of professional fights and volumes was much steeper amongst men than the relationship between number of professional fights and volumes amongst women.

While a significant moderation effect of sex was also observed on right putamen, the relationship amongst women and men differed. Amongst male fighters, higher number of professional fights was associated with smaller right putamen volume. In contrast, greater right putamen volume was associated with higher number of professional fights amongst female fighters (please see Figure 1F and Table 3). The left hippocampus, left thalamus, and bilateral caudate were not found to be significant moderators in the relationship between number of professional fights and regional brain volumes $(p>.05)$.

[PLEASE INSERT FIGURE 1A-F AND TABLE 3 HERE] 
medRxiv preprint doi: https://doi.org/10.1101/2020.06.19.20135897; this version posted June 20, 2020. The copyright holder for this preprint (which was not certified by peer review) is the author/funder, who has granted medRxiv a license to display the preprint in perpetuity.

All rights reserved. No reuse allowed without permission.

Bennett-Sex Differences in Fighters

Sex as a moderator of the relationship between fight exposure and cognitive performance

A significant moderation effect of sex was also observed on CNS Vital Signs Verbal

Memory and Reaction Time performance. While lower Verbal Memory performance was associated with a higher number of professional fights in male fighters, Verbal Memory performance was positively associated with number of professional fights amongst female fighters (please see Figure 2A and Table 4). Looking at CNS Vital Signs Reaction Time performance, which is reverse scored with lower scores equating to a faster, better performance, while the Reaction Time performance of both male and female fighters was found to be better with greater number of professional fights, the relationship between number of professional fights and Reaction Time performance was much steeper amongst men than the relationship between number of professional fights and Reaction Time performance amongst women (please see Figure 2B and Table 4).

\section{[PLEASE INSERT FIGURE 2A-B AND TABLE 4 HERE]}

Sex was not found to be a significant moderator in the relationship between number of professional fights and performance on measures of processing speed (CNS Vital Signs Processing Speed, Trails A, timed reading task), psychomotor speed (CNS Vital Signs Psychomotor Speed), language (semantic fluency, word reading task), or executive functioning (letter fluency, Trails B; all p's>.05).

\section{DISCUSSION}

The current findings reveal key insights into sex-based differences. When accounting for whole brain volume, women were found to have larger left amygdala than men. While prior research is equivocal, a recent meta-analysis suggests the amygdalae are not sexually dimorphic (Marwha, Halari, \& Eliot, 2017). Additional sex-based differences emerged when exploring the 
medRxiv preprint doi: https://doi.org/10.1101/2020.06.19.20135897; this version posted June 20, 2020. The copyright holder for this preprint (which was not certified by peer review) is the author/funder, who has granted medRxiv a license to display the preprint in perpetuity.

All rights reserved. No reuse allowed without permission.

Bennett-Sex Differences in Fighters

role of sex as a moderator of the relationship between fight exposure and regional brain volumes or cognitive performance.

With regard to regional brain volumes, relevant subcortical smaller volumes were associated with greater number of professional fights amongst both male and female fighters. Notably, the relationship between number of professional fights and regional brain volumes were observed to be much steeper in men. Interestingly, while a significant moderation effect of sex was observed on right putamen such that lower volumes in men were associated with higher number of professional fights, an inverse relationship was observed amongst women. Notably, a level of noise exists in the measurement of regional brain volumes via MRI. Prior research has found that the test- retest differences of structures is up to five percent, so the association between number of professional fights and larger volumes in the right putamen may reflect the noise of the measure itself (Iscan et al., 2015). Alternatively, as the putamen is a highly connected brain region, it may be that as volumes of other surrounding regions are decreasing, the volume of the putamen increases in an effort to compensate. In addition, prior research suggests that the basal ganglia may be one of the earliest brain regions to manifest inflammation in some disease processes (e.g., HIV; Wright et al., 2016). It may be that the slight observed "growth" in the right putamen is actually a reflection of inflammation in response to exposure to repetitive head impact.

Sex also moderated the relationship between number of professional fights and two aspects of cognitive functioning, Verbal Memory and Reaction Time. Notably, a greater number of professional fights was associated with poorer Verbal Memory performance amongst male fighters, while an inverse relationship was observed amongst female fighters. Recent research has demonstrated that factors impacting hormones (e.g., use of hormonal contraceptives) in 
medRxiv preprint doi: https://doi.org/10.1101/2020.06.19.20135897; this version posted June 20, 2020. The copyright holder for this preprint (which was not certified by peer review) is the author/funder, who has granted medRxiv a license to display the preprint in perpetuity.

All rights reserved. No reuse allowed without permission.

Bennett-Sex Differences in Fighters

women younger than the age of 65 can have a profound impact on cognitive functioning, with the strongest association between verbal memory and hormonal contraceptive use (Maki \& Sundermann, 2009). As age was observed to be highly collinear with number of professional fights, it may be that as number of professional fights and age increased, so too does opportunity for increased hormonal contraceptive use amongst female fighters. Another study has shown how pre-menopausal women (mean age $=24.2$ ) taking oral contraceptives had improved verbal memory compared to women not taking oral contraceptives (mean age $=25.69)$, which may also contribute to the inverse relationship discovered in our female cohort (mean age $=31$; Mordecai, Rubin, \& Maki, 2008). In contrast, the poorer Reaction Time performance amongst both male and female fighters was associated with higher number of professional fights. Notably, the relationship between Reaction Time performance and number of professional fights was much steeper amongst men.

While smaller regional brain volumes and poorer cognitive performance was largely associated with higher number of professional fights in both men and women, female fighters were consistently less negatively impacted than male fighters. This may reflect lower velocity punches, greater resilience, or a combination of multiple factors. For example, Kimm and Thiel (2015) found that while velocity of punches increases with experience (i.e. more fights) for all fighters, regardless of gender, women have lower velocity punches than men at all levels of experience. These findings also suggest as NoPF rise, so too does velocity of punches and, subsequently, risk of head injury to the fighter's opponent. Another recent study examined backward arm cranking power output as a proxy for punch power output, demonstrating that men's "muscle performance for protracting the arm to propel the first forward" was significantly greater than their female counterparts' performance (Morris, Link, Martin, \& Carrier, 2020). The 
medRxiv preprint doi: https://doi.org/10.1101/2020.06.19.20135897; this version posted June 20, 2020. The copyright holder for this preprint (which was not certified by peer review) is the author/funder, who has granted medRxiv a license to display the preprint in perpetuity.

All rights reserved. No reuse allowed without permission.

Bennett-Sex Differences in Fighters

described discrepancy in punch velocity may also explain why female fighters appear to show less delirious cognitive and regional brain volume impact.

The current findings are further supported by prior PFBHS research outcomes that demonstrate volumetric reduction and negative impacts on cognitive performance with increased head injury exposure (i.e., increased NoPF). One study using NoPF and years of fighting as a proxy for head injury exposure, found increased exposure was associated with decreased thalamic and caudate volumes, as well as poorer processing speed performance (Bernick 2015). Similarly, when comparing boxers, mixed martial artists, and martial artists, fighting style was observed to moderate the relationship between NoPF, cognitive performance, and regional brain volumes (Stephen, 2019).

Though the PFBHS is highly unique in that the data reflects a large cohort of professional fighters, various limitations of the current study must be considered. Less than 10 percent of the entire PFBHS sample is female. As the cohort of female fighters is significantly smaller than the cohort of male fighters, only baseline data could be considered in an effort to retain as many participants as possible and preserve statistical power. Notably, as the cohort of martial artists practice a wide variety of fighting styles (e.g., kickboxing, Muay Thai, taekwondo, and jiu-jitsu), the martial arts cohort may reflect a wide range of exposure to repetitive head impact. Similarly, number of professional fights (NoPF) only accounts for professional matches. As such, the impact of training for and participating in amateur matches is not considered. Additionally, rather than considering $\mathrm{KO} / \mathrm{TKO}$ from professional matches alone, NoPF was utilized as a proxy for head impact exposure (inclusive of subconcussive and concussive impacts) across the period of training for and participating in professional level matches. Moreover, fighters' weight classes were not considered, but may impact the incidence and severity of repetitive head impact. As 
medRxiv preprint doi: https://doi.org/10.1101/2020.06.19.20135897; this version posted June 20, 2020. The copyright holder for this preprint (which was not certified by peer review) is the author/funder, who has granted medRxiv a license to display the preprint in perpetuity.

All rights reserved. No reuse allowed without permission.

Bennett-Sex Differences in Fighters

approximately 40 analyses (some including covariates and multiple variables) were completed, an increased potential for false positives is acknowledged. One counterintuitive finding (i.e. larger putamen volumes among women with more exposure) was observed, indicating additional research is required. Finally, additional, unconsidered factors (i.e., drug use, socioeconomic status, genetic predisposition) may contribute to declines in cognitive functioning and regional brain volumes, rather than exposure to repetitive head impact alone.

As collection of data is ongoing, further analyses exploring changes over time when accounting for sex differences may provide insight into longer term discrepancies in regional brain volumes and cognitive functioning. These baseline results do not necessarily imply differences in long-term impacts of repetitive head impact as a function of sex, but longitudinal data over time comparing male and female fighters may have predictive value. Comparing male and female retired fighters may also provide some information about the long-term concussive impact differences.

In summary, this study adds to our understanding that sex-based cognitive and volumetric differences in response to repetitive head impact exist amongst fighters. The main finding is that sex is an important moderator in the relationship between number of professional fights, aspects of cognitive functioning, and brain volumes of numerous regions. While smaller regional brain volumes and poorer cognitive performance were generally associated with greater number of professional fights amongst men and women, female fighters were consistently less negatively impacted than male fighters. 
medRxiv preprint doi: https://doi.org/10.1101/2020.06.19.20135897; this version posted June 20, 2020. The copyright holder for this preprint (which was not certified by peer review) is the author/funder, who has granted medRxiv a license to display the preprint in perpetuity. All rights reserved. No reuse allowed without permission.

Bennett-Sex Differences in Fighters

\section{FUNDING}

This work was supported by Belator; Ultimate Fighting Competition (UFC); the August Rapone Family Foundation; Top Rank; Haymon Boxing; and an Institutional Development Award (S.B., IDeA NIGMS; P20GM109025).

\section{ACKNOWLEDGEMENTS}

Conflicts of Interest

None 
medRxiv preprint doi: https://doi.org/10.1101/2020.06.19.20135897; this version posted June 20, 2020. The copyright holder for this preprint (which was not certified by peer review) is the author/funder, who has granted medRxiv a license to display the preprint in perpetuity.

Bennett-Sex Differences in Fighters

\section{REFERENCES}

Bernick, C., Banks, S., Phillips, M., Lowe, M., Shin, W., Obuchowski, N., ... \& Modic, M. (2013). Professional fighters brain health study: rationale and methods. American Journal of Epidemiology, 178(2), 280-286.

Bernick, C., \& Banks, S. (2013). What boxing tells us about repetitive head trauma and the brain. Alzheimer's Research \& Therapy, 5(3), 23.

Bernick, C., Banks, S. J., Shin, W., Obuchowski, N., Butler, S., Noback, M., ... \& Modic, M. (2015). Repeated head trauma is associated with smaller thalamic volumes and slower processing speed: the Professional Fighters' Brain Health Study. British Journal of Sports Medicine, 49(15), 1007-1011.

Chamard, E., Lefebvre, G., Lassonde, M., \& Theoret, H. (2016). Long-term abnormalities in the corpus callosum of female concussed athletes. Journal of Neurotrauma, 33(13), 12201226.

Covassin, T., Elbin, R. J., Bleecker, A., Lipchik, A., \& Kontos, A. P. (2013). Are there differences in neurocognitive function and symptoms between male and female soccer players after concussions?. The American Journal of Sports Medicine, 41(12), 28902895.

Covassin, T., Moran, R., \& Elbin, R. J. (2016). Sex differences in reported concussion injury rates and time loss from participation: an update of the National Collegiate Athletic Association Injury Surveillance Program from 2004-2005 through 2008-2009. Journal of Athletic Training, 51(3), 189-194. 
medRxiv preprint doi: https://doi.org/10.1101/2020.06.19.20135897; this version posted June 20, 2020. The copyright holder for this preprint (which was not certified by peer review) is the author/funder, who has granted medRxiv a license to display the preprint in perpetuity. All rights reserved. No reuse allowed without permission.

\section{Bennett-Sex Differences in Fighters}

Fakhran, S., Yaeger, K., Collins, M., \& Alhilali, L. (2014). Sex differences in white matter abnormalities after mild traumatic brain injury: localization and correlation with outcome. Radiology, 272(3), 815-823.

Fischl, B. (2012). FreeSurfer. Neuroimage, 62(2), 774-781.

Frommer, L. J., Gurka, K. K., Cross, K. M., Ingersoll, C. D., Comstock, R. D., \& Saliba, S. A. (2011). Sex differences in concussion symptoms of high school athletes. Journal of Athletic Training, 46(1), 76-84.

Gualtieri, C. T., \& Johnson, L. G. (2006). Reliability and validity of a computerized neurocognitive test battery, CNS Vital Signs. Archives of Clinical Neuropsychology, 21(7), 623-643.

Iscan, Z., Jin, T. B., Kendrick, A., Szeglin, B., Lu, H., Trivedi, M., ... \& Adams, P. (2015). Testretest reliability of FreeSurfer measurements within and between sites: effects of visual approval process. Human Brain Mapping, 36(9), 3472-3485.

Iverson, G. L., Brooks, B. L., \& Ashton Rennison, V. L. (2014). Minimal gender differences on the CNS vital signs computerized neurocognitive battery. Applied Neuropsychology: Adult, 21(1), 36-42.

Kimm, D., \& Thiel, D. V. (2015). Hand Speed Measurements in Boxing. Procedia Engineering, 112, 502-506. doi: 10.1016/j.proeng.2015.07.232

Lee, B., Bennett, L. L., Bernick, C., Shan, G., \& Banks, S. J. (2019). The relations among depression, cognition, and brain volume in professional boxers: a preliminary examination using brief clinical measures. Journal of Head Trauma Rehabilitation. Advance online publication. doi: 10.1097/HTR.0000000000000495 
medRxiv preprint doi: https://doi.org/10.1101/2020.06.19.20135897; this version posted June 20, 2020. The copyright holder for this preprint (which was not certified by peer review) is the author/funder, who has granted medRxiv a license to display the preprint in perpetuity. All rights reserved. No reuse allowed without permission.

\section{Bennett-Sex Differences in Fighters}

Lincoln, A. E., Caswell, S. V., Almquist, J. L., Dunn, R. E., Norris, J. B., \& Hinton, R. Y. (2011). Trends in concussion incidence in high school sports: a prospective 11-year study. The American Journal of Sports Medicine, 39(5), 958-963.

Maki PM, Sundermann E. Hormone therapy and cognitive function. Hum Reprod Update. 2009;15(6):667-681. doi:10.1093/humupd/dmp022

Marar, M., McIlvain, N. M., Fields, S. K., \& Comstock, R. D. (2012). Epidemiology of concussions among United States high school athletes in 20 sports. The American Journal of Sports Medicine, 40(4), 747-755.

Marwha, D., Halari, M., \& Eliot, L. (2017). Meta-analysis reveals a lack of sexual dimorphism in human amygdala volume. Neuroimage, 147, 282-294.

Merritt, V. C., Padgett, C. R., \& Jak, A. J. (2019). A systematic review of sex differences in concussion outcome: what do we know?. The Clinical Neuropsychologist, 1-28.

Mordecai, K. L., Rubin, L. H., \& Maki, P. M. (2008). Effects of menstrual cycle phase and oral contraceptive use on verbal memory. Hormones and Behavior, 54(2), 286-293. doi: 10.1016/j.yhbeh.2008.03.006

Morris, J. S., Link, J., Martin, J. C., \& Carrier, D. R. (2019). Sexual dimorphism in human arm power and force: implications for sexual selection on fighting ability. The Journal of Experimental Biology, 223(2). doi: 10.1242/jeb.212365

Nevada State Athletic Commission, Nevada Department of Business and Industry (n.d.). Results. Retrieved from: http://boxing.nv.gov/

Schultz, V., Stern, R. A., Tripodis, Y., Stamm, J., Wrobel, P., Lepage, C., ... \& Baugh, C. M. (2018). Age at first exposure to repetitive head impacts is associated with smaller 
medRxiv preprint doi: https://doi.org/10.1101/2020.06.19.20135897; this version posted June 20, 2020. The copyright holder for this preprint (which was not certified by peer review) is the author/funder, who has granted medRxiv a license to display the preprint in perpetuity. All rights reserved. No reuse allowed without permission.

Bennett-Sex Differences in Fighters

thalamic volumes in former professional American football players. Journal of Neurotrauma, 35(2), 278-285.

Sollmann, N., Echlin, P. S., Schultz, V., Viher, P. V., Lyall, A. E., Tripodis, Y., ... \& Johnson, A. M. (2018). Sex differences in white matter alterations following repetitive subconcussive head impacts in collegiate ice hockey players. Neuroimage: Clinical, 17, 642-649.

Stephen, S. J., Shan, G., Banks, S. J., Bernick, C., \& Bennett, L. L. (2019). The Relationship Between Fighting Style, Cognition, and Regional Brain Volume in Professional Combatants: A Preliminary Examination Using Brief Neurocognitive Measures. The Journal of head trauma rehabilitation, 10.1097/HTR.0000000000000540. Advance online publication. https://doi.org/10.1097/HTR.0000000000000540

Wright, P. W., Pyakurel, A., Vaida, F. F., Price, R. W., Lee, E., Peterson, J., ... \& Meyerhoff, D. J. (2016). Putamen volume and its clinical and neurological correlates in primary HIV infection. AIDS (London, England), 30(11), 1789.

Zuckerman, S. L., Kerr, Z. Y., Yengo-Kahn, A., Wasserman, E., Covassin, T., \& Solomon, G. S. (2015). Epidemiology of sports-related concussion in NCAA athletes from 2009-2010 to 2013-2014: incidence, recurrence, and mechanisms. The American Journal of Sports Medicine, 43(11), 2654-2662. 
medRxiv preprint doi: https://doi.org/10.1101/2020.06.19.20135897; this version posted June 20, 2020. The copyright holder for this preprint (which was not certified by peer review) is the author/funder, who has granted medRxiv a license to display the preprint in perpetuity.

All rights reserved. No reuse allowed without permission.

Bennett-Sex Differences in Fighters

\section{TABLES}

Table 1. 2015 to 2017 Nevada commission fight records

\begin{tabular}{|r|l|l|l|l|l|}
\hline & KO & TKO & Decision/Draw & Submission & $\begin{array}{l}\text { Total (\% } \\
\text { KO/TKO) }\end{array}$ \\
\hline Boxer Men & 33 & 170 & 296 & N/A & $500(41)$ \\
\hline Women & 1 & 168 & 288 & - & $489(41)$ \\
\hline MMA & 14 & 2 & 8 & - & $11(27)$ \\
\hline Men & 12 & 136 & 263 & 137 & $550(27)$ \\
\hline Women & 2 & 13 & 225 & 107 & $467(29)$ \\
\hline Martial Arts & 4 & 14 & 38 & 30 & $83(18)$ \\
\hline Men & 4 & 12 & 34 & N/A & $52(35)$ \\
\hline Women & 0 & 2 & 2 & - & $48(33)$ \\
\hline
\end{tabular}

Note: Decision/Draw includes any result labeled as unanimous decision, split decision, draw, or majority decision. Submission includes any result labeled as choke outs, tap out, or submission. Outcomes of fights that were later changed to "no decision" or labeled as "cancelled" were not included in this count. 
medRxiv preprint doi: https://doi.org/10.1101/2020.06.19.20135897; this version posted June 20, 2020. The copyright holder for this preprint (which was not certified by peer review) is the author/funder, who has granted medRxiv a license to display the preprint in perpetuity. All rights reserved. No reuse allowed without permission.

Bennett-Sex Differences in Fighters

Table 2. Participant demographic data.

\begin{tabular}{|c|c|c|c|}
\hline & $\begin{array}{l}\text { Fighters }(\mathrm{n}= \\
110)\end{array}$ & $\begin{array}{l}\text { Male fighters ( } \mathrm{n} \\
=55)\end{array}$ & $\begin{array}{l}\text { Female fighters } \\
(\mathrm{n}=55)\end{array}$ \\
\hline Age (mean [SD]) & $30.7(6.7)$ & $30.9(6.9)$ & $30.6(6.6)$ \\
\hline Education (mean [SD]) & $14.0(3.7)$ & $13.9(3.7)$ & $14.2(3.8)$ \\
\hline $\begin{array}{l}\text { Number of professional fights } \\
\text { (mean [SD]) }\end{array}$ & $12.8(15.8)$ & $12.4(12.6)$ & $13.3(18.5)$ \\
\hline Active fighters & 101 & 49 & 52 \\
\hline \multicolumn{4}{|l|}{ Type of fighting } \\
\hline Boxers $(\%)$ & $32(29.1)$ & $15(27.3)$ & $17(30.9)$ \\
\hline MMAs (\%) & $69(62.7)$ & $38(69.1)$ & $31(56.4)$ \\
\hline MAs (\%) & $9(8.2)$ & $2(3.6)$ & $7(12.7)$ \\
\hline Years of education completed & 108 & & \\
\hline Middle school (\%) & $1(0.9)$ & & \\
\hline Some high school (\%) & $2(1.9)$ & & \\
\hline High school (\%) & $22(20.4)$ & & \\
\hline Some college $(\%)$ & $8(7.4)$ & & \\
\hline Associate's degree (\%) & $31(28.7)$ & & \\
\hline Bachelor's degree (\%) & $36(33.3)$ & & \\
\hline Some graduate school (\%) & $1(0.9)$ & & \\
\hline Master's degree (\%) & $6(5.6)$ & & \\
\hline Doctoral degree $(\%)$ & $1(0.9)$ & & \\
\hline \multicolumn{4}{|l|}{ Number of professional fights } \\
\hline $0(\%)$ & & $21(19.1)$ & \\
\hline $1-10(\%)$ & & $39(35.5)$ & \\
\hline $11-20(\%)$ & & $27(24.6)$ & \\
\hline $21-30(\%)$ & & $13(11.8)$ & \\
\hline $31-40(\%)$ & & $5(4.5)$ & \\
\hline $41-50(\%)$ & & 0 & \\
\hline $51-60(\%)$ & & $3(2.7)$ & \\
\hline 61 or more $(\%)$ & & $2(1.8)$ & \\
\hline
\end{tabular}

Note: As male and female fighters were matched, there were no significant differences between male and female fighters with regard to age, years of education, ethnicity, and type of fighting (e.g., boxer, MMA, MAs; all $P^{\prime}$ 's > .2) 
medRxiv preprint doi: https://doi.org/10.1101/2020.06.19.20135897; this version posted June 20, 2020. The copyright holder for this preprint (which was not certified by peer review) is the author/funder, who has granted medRxiv a license to display the preprint in perpetuity.

All rights reserved. No reuse allowed without permission.

Bennett-Sex Differences in Fighters

Table 3. Moderation effect of sex on subcortical regional brain volumes

\begin{tabular}{|l|l|l|l|l|l|}
\hline & $P$ & $b$ & $\begin{array}{l}95 \% \text { confidence } \\
\text { interval }\end{array}$ & $\begin{array}{l}\text { Slope of male } \\
\text { fighters }\end{array}$ & $\begin{array}{l}\text { Slope of } \\
\text { female fighters }\end{array}$ \\
\hline $\begin{array}{l}\text { Right } \\
\text { hippocampus }\end{array}$ & 0.015 & -6.10 & -10.95 to -1.25 & -15.37 & -3.17 \\
\hline Right thalamus & 0.020 & -13.45 & -24.70 to -2.21 & -30.60 & -3.69 \\
\hline Left putamen & 0.046 & -8.74 & -17.30 to -0.18 & -17.48 & -2.99 \\
\hline Left amygdala & 0.002 & -4.79 & -7.77 to -1.82 & -10.53 & -0.94 \\
\hline Right amygdala & 0.007 & -4.21 & -7.20 to -1.21 & -9.06 & -0.65 \\
\hline Right putamen & 0.015 & -8.68 & -10.95 to -1.25 & -16.62 & 0.73 \\
\hline
\end{tabular}


medRxiv preprint doi: https://doi.org/10.1101/2020.06.19.20135897; this version posted June 20, 2020. The copyright holder for this preprint (which was not certified by peer review) is the author/funder, who has granted medRxiv a license to display the preprint in perpetuity.

All rights reserved. No reuse allowed without permission.

Bennett-Sex Differences in Fighters

Table 4. Moderation effect of sex on subcortical regional brain volumes

\begin{tabular}{|l|l|l|l|l|l|}
\hline & $p$ value & $b$ & $\begin{array}{l}95 \% \text { confidence } \\
\text { interval }\end{array}$ & $\begin{array}{l}\text { Slope of male } \\
\text { fighters }\end{array}$ & $\begin{array}{l}\text { Slope of } \\
\text { female fighters }\end{array}$ \\
\hline $\begin{array}{l}\text { CNS Vital Signs } \\
\text { Verbal Memory }\end{array}$ & $<0.0001$ & -0.23 & -0.33 to -0.14 & -0.34 & 0.1262 \\
\hline $\begin{array}{l}\text { CNS Vital Signs } \\
\text { Reaction Time }\end{array}$ & 0.046 & 2.23 & -0.037 to 4.42 & 5.33 & 0.8708 \\
\hline
\end{tabular}


medRxiv preprint doi: https://doi.org/10.1101/2020.06.19.20135897; this version posted June 20, 2020. The copyright holder for this preprint (which was not certified by peer review) is the author/funder, who has granted medRxiv a license to display the preprint in perpetuity. All rights reserved. No reuse allowed without permission.

Bennett-Sex Differences in Fighters

\section{FIGURES LEGENDS}

Figure 1. Relationship between number of professional fights and subcortical regional brain volumes $\left(\mathrm{mm}^{\wedge} 3\right)$ by sex: A) right hippocampus, B) right thalamus, C) left putamen, D) left amygdala, E) right amygdala, and F) right putamen

Figure 2. Relationship between number of professional fights and CNS Vital Signs performance by sex: A) Verbal Memory Subject Score (raw number correct) B) Reaction Time Subject Score (reverse scored; milliseconds)

Note: As CNS VS Reaction Time is reverse scored, graph depicts maximum score - raw score for each participant and is reported in milliseconds 


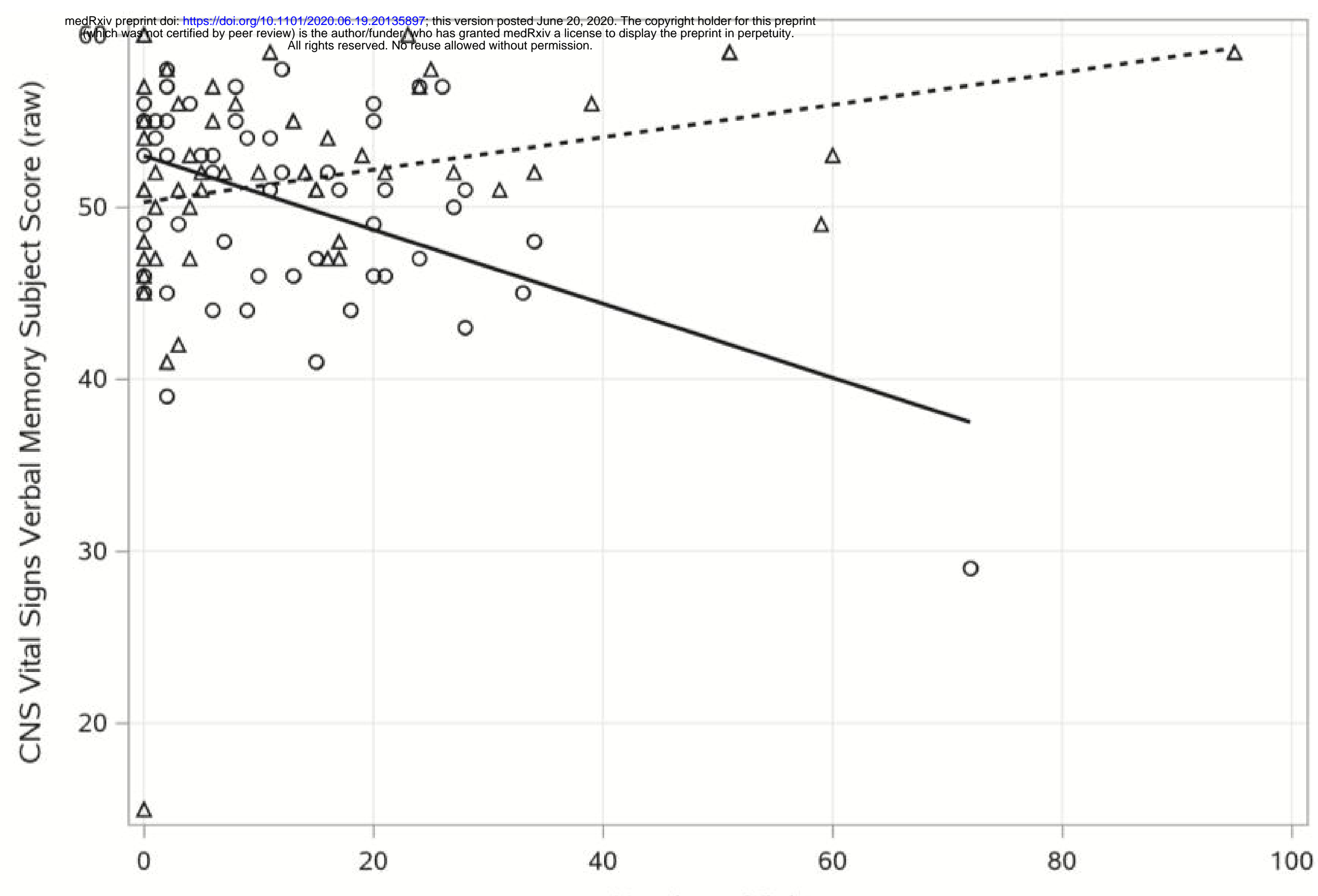

A) O Male $\triangle$ Female $\longrightarrow$ Male...... Female

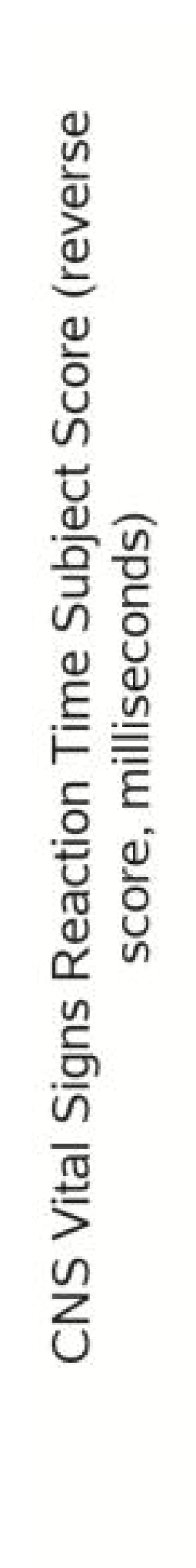

B)

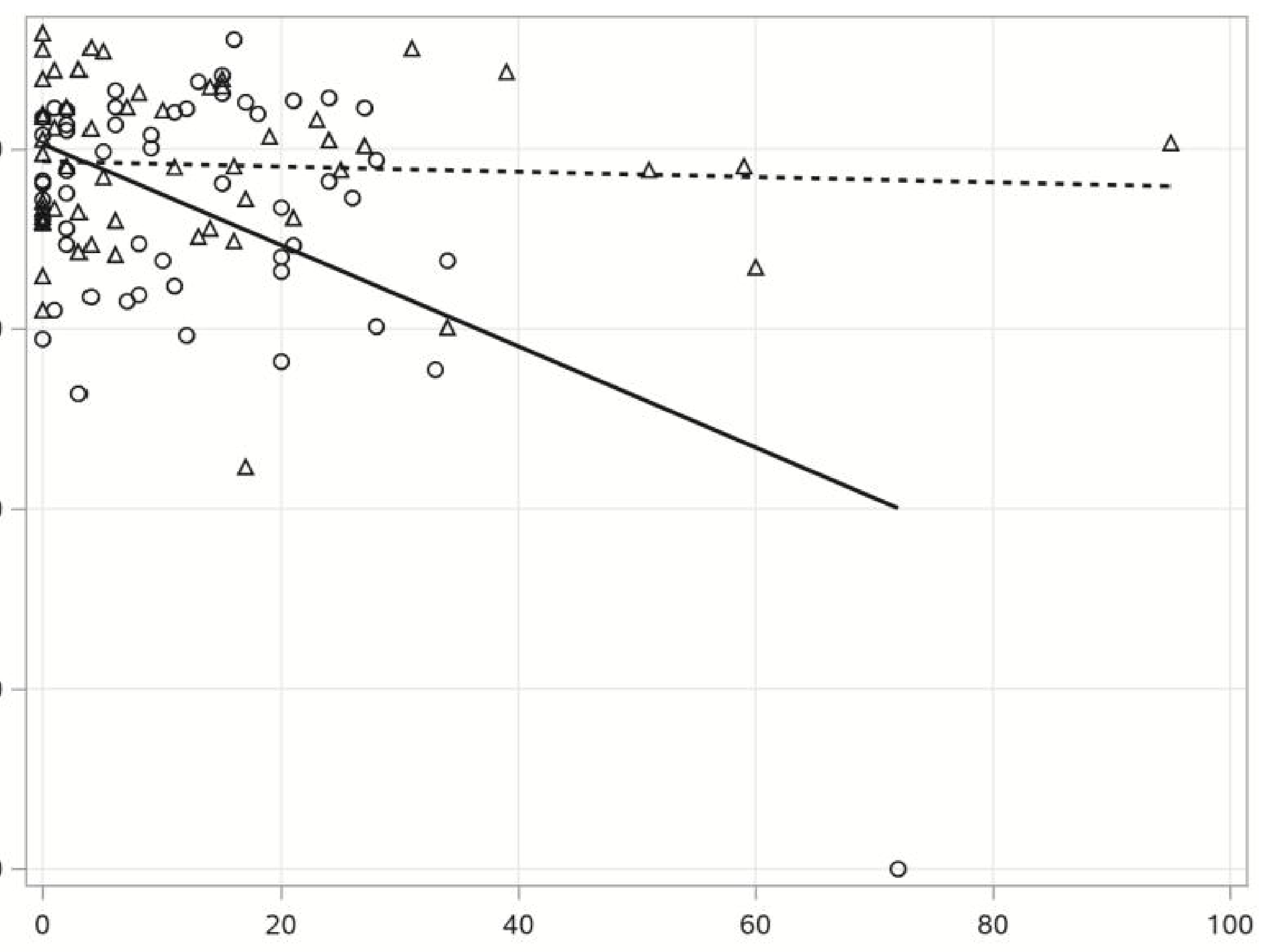

Number of fights

Figure 2. Relationship between NoPF and CNS Vital Signs performance by sex: A) Verbal Memory Subject Score B) Reaction Time Subject Score (Note: As CNS VS Reaction Time, is reverse scored, graph depicts maximum score - raw score for each participant) 